\title{
COMPARISON OF THE EFFECT OF PLASMAPHERESIS AND PENICILLAMINE ON THE LEVEL OF CIRCULATING RHEUMATOID FACTOR*
}

\author{
BY \\ ISRAELI A. JAFFE \\ Rheumatic Disease Service, N.Y. Medical College Metropolitan Medical Center, N.Y.
}

Gamma macroglobulins, such as rheumatoid factor, are readily dissociated by sulphhydrylreducing compounds into smaller globulin fragments (Deutsch and Morton, 1957). When rheumatoid factor (RF) is incubated in vitro with cysteine or mercaptoethanol, immunological reactivity is irreversibly lost, although macromolecular structure returns after dialysis of the thiol (Heimer and Federico, 1958). Previous studies have shown that the instillation of sulphhydryl-reducing compounds into the knee joints of rheumatoid patients with synovitis and effusion results in a transient reversal of the sero-positivity of the synovial fluid (Jaffe, 1962a).

Penicillamine, a low molecular weight sulphhydryl amino acid, is capable of producing this dissociation of rheumatoid macroglobulin in vitro and in synovial fluid following intra-articular injection (ibid.). Though it is a relatively weak sulphhydryl-reducing agent in vitro, it has a favourable therapeutic ratio based upon the clinical experience in patients with Wilson's disease (Scheinberg and Sternlieb, 1960). The D-isomer is apparently less toxic than the $\mathrm{L}$ form of the drug (Aposhian and Aposhian, 1959).

Systemic administration of penicillamine to rheumatoid arthritics, at first believed to be without effect, does result in a definite reduction in the titre of circulating RF, provided it is given for prolonged periods. Not only may many weeks be required before the fall begins, but even longer periods elapse after stopping the drug before the titre returns to control values (Jaffe, 1962b).

Plasmapheresis is a technique by which the serum globulins may be lowered by repeated phlebotomies, separation of the plasma, and re-infusion of the patients own red cells. It has been successfully employed to reduce the level of circulating macroglobulin in patients with Waldenstrom's macroglobulinaemia and increased serum viscosity (Schwab

- Based on a paper presented before the 9th Interim Scientific Session of the American Rheumatism Association, Richmond, Virginia, in December, 1962. This work was supported by the Health Research Council of the City of New York (U-1097) and by the Arthritis and Rheumatism Foundation. and Fahey, 1960). It seemed of interest to contrast the effect of these two modalities, penicillamine and plasmapheresis, upon the level of circulating rheumatoid factor, with particular regard to the recovery phase after each procedure.

\section{Methods}

Rheumatoid factor titre was determined by the quantitative precipitin technique (Edelman, Kunkel, and Franklin, 1958). RF reacts directly with heat aggregated human gamma globulin (Cohn Fraction II, Lederle) to form a precipitate. Increasing amounts of gamma globulin are added serially to the serum and the protein content of the resulting precipitates is determined. The serum must be diluted with saline until a curve is obtained which falls in the zone of antigen excess. Thus the height of the titre is expressed as the degree of serum dilution required and the height of the curve (mg. protein per sample). All sera were assayed in duplicate and a standard test serum of known titre was always included as a further control on each run.

Plasmapheresis.-Two units of blood, $500 \mathrm{ml}$. each, were removed at each plasmapheresis. The blood was collected in a special plasmapheresis pack (Fenwall) with ACD solution as the anticoagulant. After collection, the blood was immediately separated in a refrigerated centrifuge $\left(4^{\circ}\right.$ C.) for 30 min. at 2,500 r.p.m. By the completion of the second phlebotomy, the red cells from the first were ready for re-infusion. The entire procedure was accomplished through a single venepuncture and took about 2 hours. The average yield was $600 \mathrm{ml}$. plasma. The procedure was performed daily for the first 5 days, and the patient was then given a 2-day rest period. On the 8th day another plasmapheresis was performed and on the final 2 days of the study the procedure was done both in the morning and in the afternoon. Serum samples for assay of RF titre were obtained immediately before each plasmapheresis and daily thereafter until the level returned to the control value.

Penicillamine.-One week after return to control, DL-penicillamine was begun in a dosage of $0.5 \mathrm{~g}$. four times daily. Precipitin curves were determined at weekly intervals after it had been demonstrated that there were no significant day-to-day changes. When 
the titre had fallen to a level comparable to that achieved by plasmapheresis, the medication was stopped, and serial follow-up determinations of RF titre were made.

\section{Clinical Material}

Case 1, a 48-year-old male with a 7-year history of rheumatoid arthritis was studied first with plasmapheresis and then penicillamine. His disease had been active and progressive for the 6 months before admission to hospital and was in Stage II (Steinbrocker, Traeger, and Batterman, 1949). His titre was moderately high, requiring a serum dilution of $1: 5$ in the precipitin test.

Case 2, a 43-year-old male with a 4-year history of rheumatoid arthritis, was treated with penicillamine only. His disease had been active for 1 year before admission, and was also in Stage II. The titre was relatively low at a $1: 2$ dilution by the precipitin test, and $1: 2,560$ by the standard quantitative latex test (Singer and Plotz, 1956).

\section{Results}

Plasmapheresis.-As shown in Fig. 1, a progressive daily fall in the level of RF was achieved. During the 2-day rest period, a return towards the control began, but subsequent plasmapheresis resulted in a further reduction. The final curve, compared with the control, indicates the total fall in RF titre achieved by the removal of approximately 61 . plasma during the 10-day study period.

Fig. 2 (opposite) shows the pattern of return after the procedure was terminated, measured daily. The titre began to rise 72 hours after the final plasmapheresis and had reached the control level by the 8 th to 9 th day.

The Table gives the values for the serum proteins determined by paper electrophoresis at the beginning and end of the plasmaphereses, and after the titre had returned to the control.

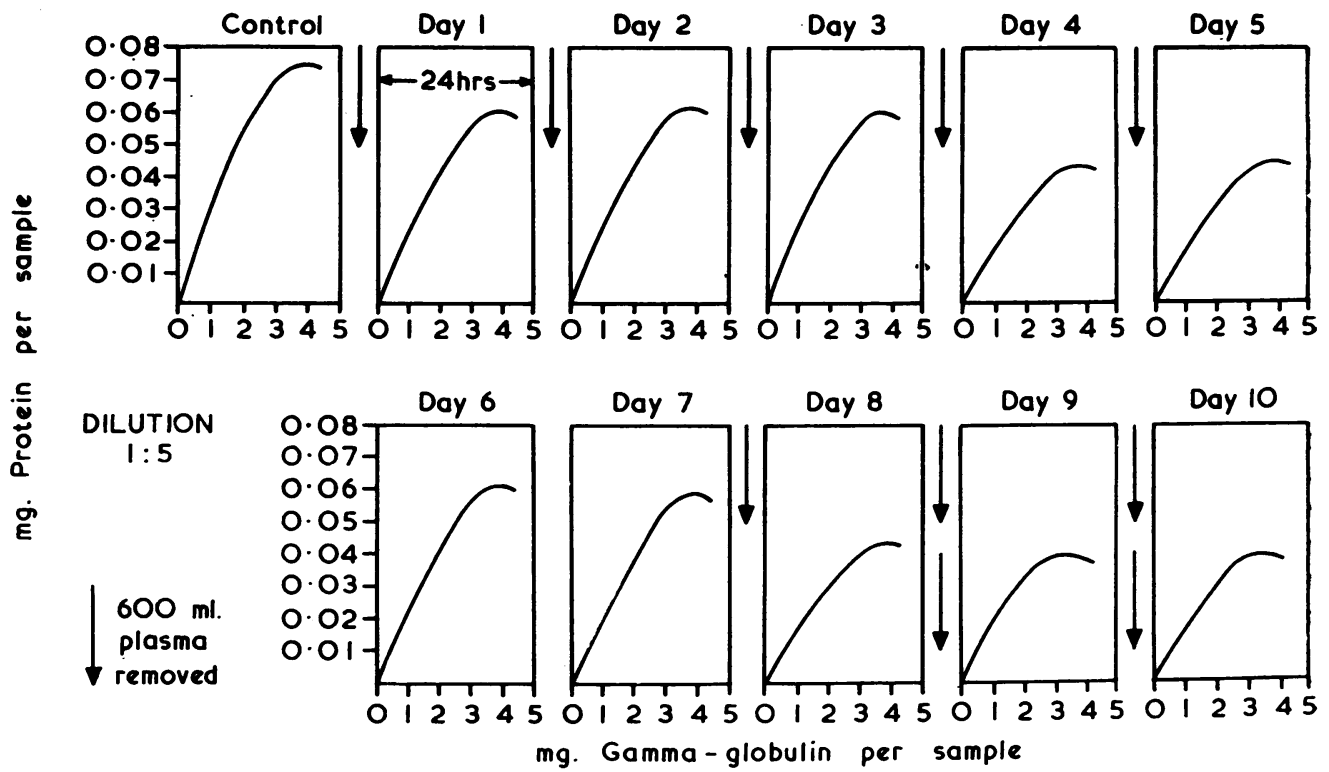

Fig. 1.--Case 1. Effect of plasmapheresis on level of circulating rheumatoid factor. Precipitin curves determined daily for 10 days.

TABLE

VALUES RECORDED FOR CASE 1

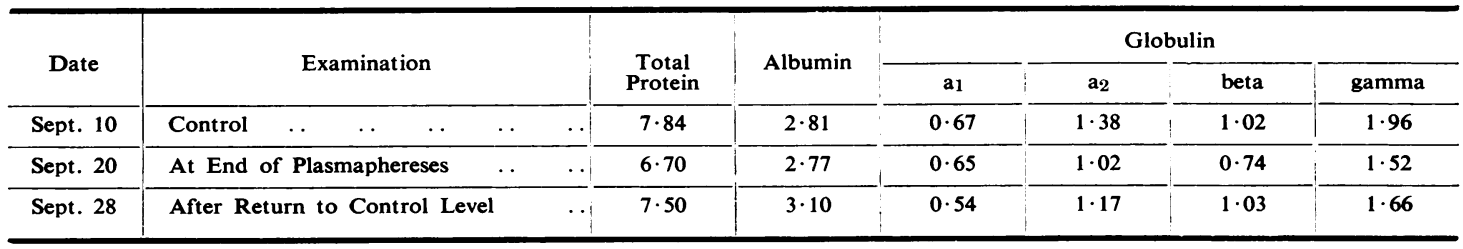




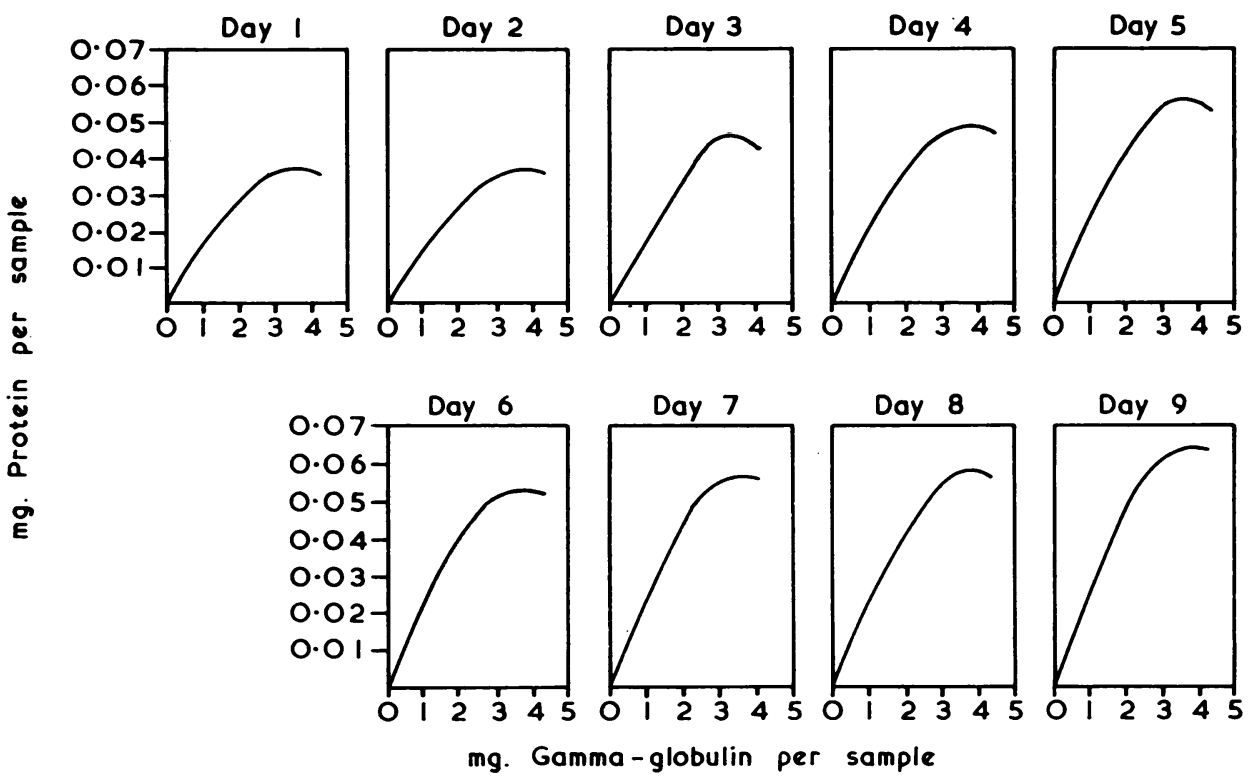

Fig. 2.-Case 1. Return of rheumatoid factor titres after completion of plasmapheresis. The level is almost back to that of the control (Fig. 1) by the 9th day. Precipitin curves determined daily for 9 days.

Penicillamine.-Fig. 3 (overleaf) shows the change in RF titre determined weekly after the institution of the drug. For the first 3 weeks there was absolutely no fall. A slight but definite reduction was observed after the 4th week, and the level continued to drop during the next fortnight. After 6 weeks of penicillamine administration, the fall in titre equalled that achieved by plasmapheresis. The medication was then stopped. For the next 4 weeks the titre remained at this same reduced level, showing no return towards the control level.

The second patient, treated only with penicillamine, had a lower initial titre $(1: 2)$ in the precipitin test. His response, Fig. 4 (overleaf) was recorded at fortnightly intervals unless otherwise indicated. While he was taking D-penicillamine a progressive fall in titre was noted, and this appeared to level off at the 6 th, 8 th, and 10 th weeks. The DL form of the drug was then directly substituted in the same dosage and a further fall was observed.

In order that these final curves should be more valid at the lowered titres, the sera were run undiluted. After 15 weeks of continuous penicillamine administration, the initial latex-fixation titre of $1: 2,560$ had fallen to $1: 320$. The followup curves show that only a slight rise occurred after the drug was stopped, and that a significant reduction persisted for 3 months on no medication whatever.

\section{Discussion}

Plasmapheresis resulted in a fall in RF by the continuous depletion of plasma protein at a rate more rapid than synthesis. The albumin fraction was not effected by the procedure, the fall in total serum protein being accounted for solely by the fall in the globulins. The rate of production of RF is obviously extremely rapid as evidenced by the rise during the 2-day rest period after the first five plasmaphereses, and by the significant but relatively slight final reduction achieved by the removal of 61 . plasma in 10 days. During the recovery period, only 9 days were required to achieve and maintain the control titre.

The rationale which led to the systemic administration of a sulphhydryl-reducing agent such as penicillamine was based upon its ability to dissociate the rheumatoid macroglobulin by the sulphhydryl-disulphide interchange in vitro and in vivo in the synovial fluid. Penicillamine is believed to be a rapidly excreted drug as evidenced by the prompt and transient cupruresis resulting from its administration to normal subjects and to patients with Wilson's disease (Scheinberg and Sternlieb, 


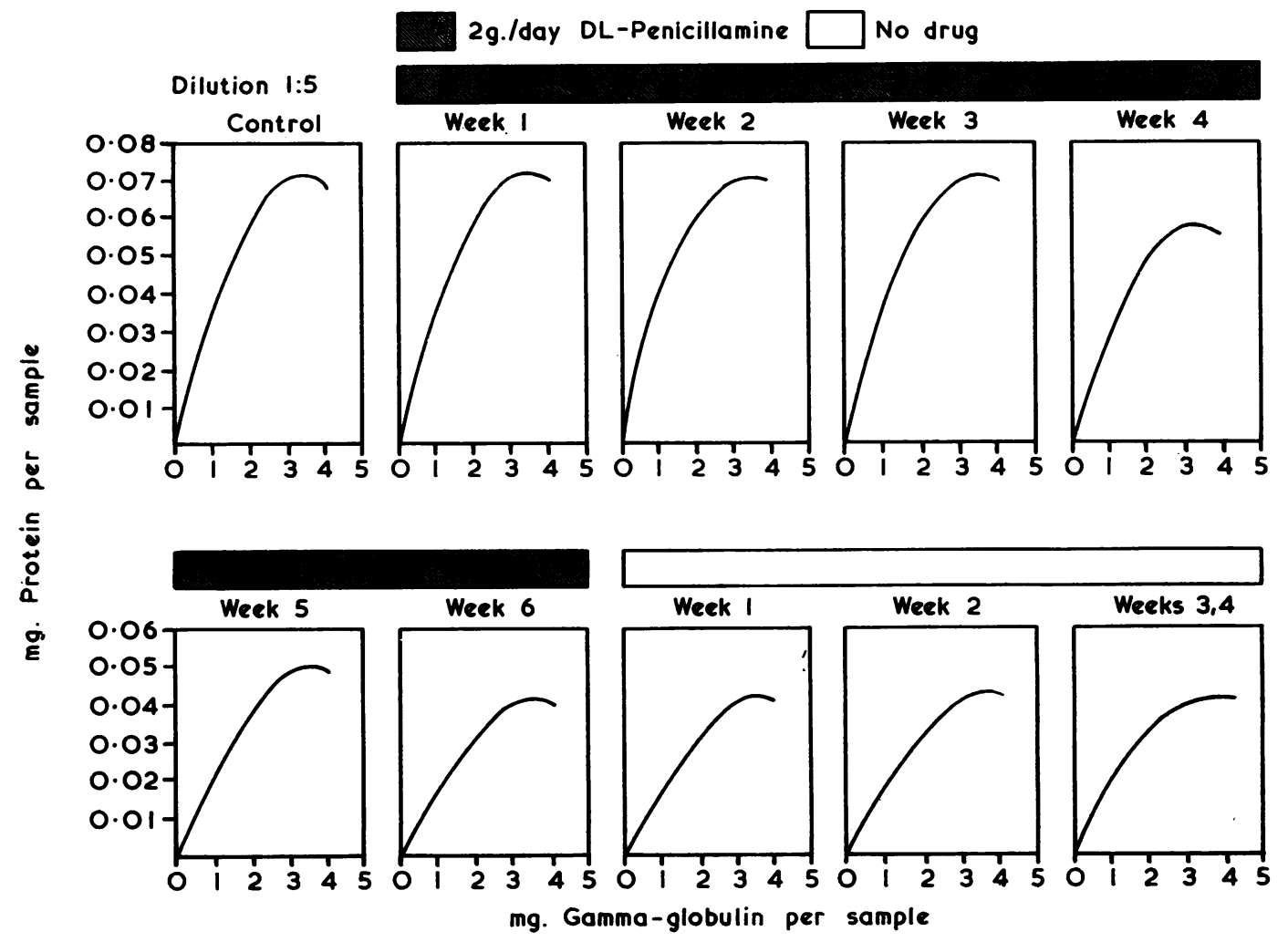

Fig. 3.-Case 1. Effect of DL-penicillamine on rheumatoid factor titres. The level did not start to fall until the 4th week and reached the value achieved by plasmapheresis (Fig. 1, Day 10) by the 6th week. The titre remained depressed for 4 weeks after stopping the drug. Precipitin curves determined weekly for a total of 10 weeks.

1960). The increase in urinary copper excretion produced by the drug ceases almost within hours after the last dose; hence it has been the practice to give it in divided doses three or four times daily. The same SH radical needed for chelation (Walshe, 1957) is also responsible for dissociation. If penicillamine were lowering the titre of RF by simply dissociating the macroglobulin within the plasma compartment, a reasonably prompt response would be expected. In effect, a "biochemical plasmapheresis" would be performed on the circulating RF.

As has been shown, the response following penicillamine and the return of the titre after it has been discontinued are quite different from those observed after plasmapheresis. The changes in RF titre associated with penicillamine administration are slow to appear and even slower to revert to the control level, suggesting a cumulative action of the drug. In the first case presented, the drug was continued only until a drop in titre comparable to that produced by plasmapheresis was reached. Thus the degree of reduction achieved by both modalities was the same. While the titre was back to the control level within 9 days of stopping plasmapheresis, it had not yet begun to rise 4 weeks after discontinuing penicillamine.

The second case illustrates the effect of a longer duration of drug administration upon a patient with a lower initial serum titre. While the data may suggest that the $\mathrm{L}$-isomer is more effective in producing the reduction, this could well have been fortuitous and may actually represent only the result of more prolonged treatment. In vitro, the D- and L-isomers show identical sulphhydrylreducing capacity (Jaffe, 1962a). The most striking feature of the second case, however, is the persistence of a significant reduction in titre 3 months after the drug had been discontinued.

Thus the mechanism by which penicillamine causes a fall in circulating RF after systemic administration is, as yet, unclear. The conclusion reached 


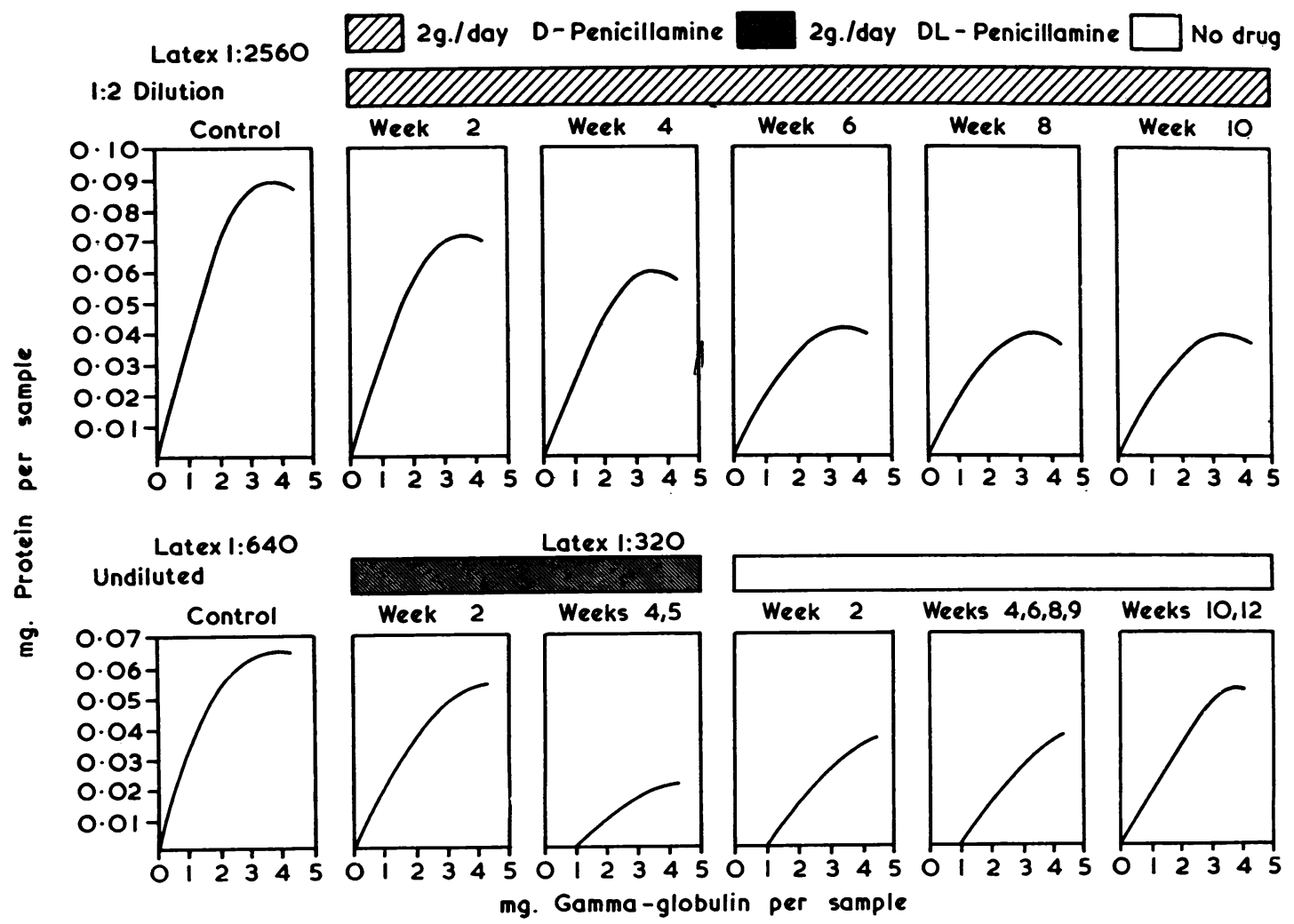

Fig. 4.-Case 2. Change in rheumatoid factor levels in a patient with lower initial serum titre (1:2) treated with D-penicillamine for 10 weeks and DL-penicillamine for a further 5 weeks. Last curve of upper row and first curve of lower row derived from the same serum. The lower curves were run undiluted because of the reduced titre. No significant rise in titre occurred for 3 months after stopping the drug. Precipitin curves determined fortnightly (unless otherwise stated) for a total of 27 weeks.

from these comparative studies is that the drug is not producing its effect by dissociation of the rheumatoid macroglobulin within the vascular compartment. If there be a large "tissue pool" of RF as has been postulated (Ball, 1962), then perhaps the sulphhydryl-reducing compound reacts preferentially with this extravascular rheumatoid factor before changes are reflected in the serum titre.

Alternatively, it must be emphasized that penicillamine has pharmacological effects other than its sulphhydryl-reducing capacity. It is a potent chelator of copper and other trace metals. L-penicillamine, in animals, has been shown to interfere with certain vitamin $\mathbf{B}_{6}$ dependent enzyme systems, suggesting that the drug may behave as a biochemical antagonist to some of the metabolic effects of the vitamin (Kuchinskas and du Vigneaud, 1957). Other animal studies have shown an impaired antibody response, including prolonged homograft survival, when vitamin $\mathbf{B}_{6}$ deficiency has been induced by conventional means (Fisher and Schewe, 1962).
Finally, penicillamine may not be acting directly on the rheumatoid factor or its synthesis. The possibility should be considered that it may be favourably influencing the underlying pathological process (in a manner not understood) which is reflected secondarily by a drop in titre, analogous to that which is sometimes seen after a successful course of gold salts or antimalarial compounds.

\section{Clinical Observations}

It is most difficult to make significant comments regarding the effect of a particular course of treatment upon the clinical course of rheumatoid arthritis when dealing with a small number of cases observed for a brief period of time. It can be stated, however, that at the conclusion of plasmapheresis no clinical change was evident. After prolonged penicillamine administration, there appeared to be objective and subjective signs of gradual clinical improvement, which first became manifest from 3 to 6 weeks after the drug had been 
started. Whether this observation simply reflects the vagaries of the disease and the placebo effect, or whether it represents a valid pharmacological response, can be answered only by further long-term administration of the compound to a large series of patients.

\section{Summary}

The influence upon the titre of RF induced by plasmapheresis and penicillamine administration has been compared. Both modalities resulted in a fall in the level of RF, but this was prompt and transient after plasmapheresis and slow in onset and more lasting in duration after penicillamine. It is suggested that the drug is not exerting its effect on RF by sulphhydryl dissociation of the macroglobulin within the vascular compartment. Other mechanisms postulated are: dissociation of tissue RF, inhibition of production of RF (perhaps by an anti-vitamin $\mathbf{B}_{6}$ action of penicillamine), or a more basic effect on the underlying disease process which is then reflected by a secondary decrease in the titre. There appeared to be a favourable clinical change associated with prolonged drug administration which merits a larger clinical trial.

\section{REFERENCES}

Aposhian, H. V., and Aposhian, M. M. (1959). J. Pharmacol., 126, 131.

Ball, J. (1962). Ann. rheum. Dis., 21, 272.

Deutsch, H. F., and Morton, J. I. (1957). Science, 125,600 .

Edelman, G. M., Kunkel, H. G., and Franklin, E. C. (1958). J. exp. Med., 108, 105.

Fisher, B., and Schewe, E. (1962). Ann. Surg., 155, 457.

Heimer, R. and Federico, O. M. (1958). Clin. chim. Acta, 3, 496.

Jaffe, I. A. (1962a). J. Lab. clin. Med., 60, 409. (1962b). Bull. rheum. Dis., 13, 284.

Kuchinskas, E. J., and du Vigneaud, V. (1957). Arch. Biochem. Biophys., 66, 1.

Scheinberg, I., and Sternlieb, I. (1960). In "Metal Binding in Medicine," 1st ed., p. 275. Lippincott, Philadelphia.

Schwab, P. J., and Fahey, J. L. (1960). New Engl. J. Med., 263, 574.
Singer, J. M., and Plotz, C. M. (1956). Amer. J. Med., 21, 888.

Steinbrocker, O., Traeger, C., and Batterman, R. C. (1949). J. Amer. med. Ass., 140, 659.

Walshe, J. M. (1957). Brit. med. Bull., 13, 132.

Comparaison de l'effet de la plasmaphérèse et de la $\stackrel{\mathbb{D}}{\mathbb{D}}$ pénicillamine sur le taux circulant du facteur rhumatismal (RF)

\section{RÉSUMÉ}

On compara l'action de la plasmaphérèse et de $\vec{\omega}$ l'administration de pénicillamine sur le titre du facteur $\stackrel{\odot}{\circ}$ rhumatismal. Les deux procédés amenèrent une chute du RF, mais elle fut rapide et ephémère après la plasmaphérèse et plus lente à commencer et plus prolongée après la pénicillamine. On pense que ce produit n'exerce in pas son effet sur le RF par la dissociation sulfhydrique de la macroglobuline dans le compartiment vasculaire. D'autres mécanismes postulés sont: dissociation du RF 윽 tissulaire, inhibition de la production du RF (peut-être une action anti-vitamine $B_{6}$ de la pénicillamine), ou bien $\bar{z}$ un effet plus essentiel sur le processus morbide sousjacent, se réfléchissant par une diminution secondaire du titre. Il parut y avoir un effet clinique favorable après l'administration prolongée de ce produit qui mérite des études plus approfondies.

\section{Comparación del efecto de la plasmaferesis y de la penicilamina sobre el nivel circulante del} factor reumatoide (RF)

\section{SUMARIO}

Se comparó la acción de la plasmaferesis y de la administración de penicilamina sobre el título del factor $\exists$ reumatoide. Ambos procedimientos resultaron en una caida del nivel del RF, que fué rápida y efímera después de $\overline{0}$ la plasmaferesis y de comienzo lento y acción más duradera después de la administración de penicilamina. Se sugiere que este producto no ejerce su efecto sobre el RF por una disociación del radical sulfidril de la macroglobulina dentro del compartimento vascular. Otros mecanismos postulados son: disociación del RF tisular, inhibición de la producción del RF (quizas una acción anti-vitamina $\mathbf{B}_{6}$ de la penicilamina), $o$ bien un efecto más esencial sobre el proceso mórbido subyacente $\frac{}{\supset}$ que luego se refleja en una baja del título secundaria. Pareció haber un efecto clínico favorable asociado con administración prolongada del producto, que merece un ensayo clínico más amplio. 